JPPKMI 2 (1) (2021) 1-10
JURNAL PENELITIAN DAN PENGEMBANGAN
KESEHATAN MASYARAKAT INDONESIA
Jttps://journal.unnes.ac.id/sju/index.php/jppkmi

\title{
Pelayanan Rumah Sehat COVID-19 Inovasi Pengendalian Mortalitas dan Morbiditas: Studi Kasus di Kabupaten Sukoharjo, Indonesia
}

\author{
Noor Alis Setiyadi ${ }^{1} \bowtie$, Ayu Khoirotul Umaroh ${ }^{2}$, Yunia Wahdiyati ${ }^{3}$, Rizma Septiyanti ${ }^{4}$ \\ ${ }^{1}$ Program Studi Kesehatan Masyarakat, Universitas Muhammadiyah Surakarta \\ ${ }^{2}$ Pascasarjana Promosi Kesehatan, Universitas Indonesia \\ ${ }^{3}$ Dinas Kesehatan Kabupaten Sukoharjo, Jawa Tengah, Indonesia \\ ${ }^{4}$ Relawan Satgas Covid-19
}

\section{Info Artikel}

Sejarah Artikel:

Diterima 22 April 2021

Disetujui 10 Juni 2021

Dipublikasi 14 Juni 2021

\section{Keywords:}

Rumah sehat covid,

Pengendalian kesakitan,

Sukoharjo

$U R L:$

https://iournal.unnes.ac.1 d/sju/index.php/ippkmi /article/view/47457

\begin{abstract}
Abstrak
Salah satu inovasi yang dilakukan oleh pemerintah Kabupaten Sukoharjo dalam penanganan COVID-19 adalah mendirikan Rumah Sehat COVID-19 sebagai tempat isolasi khusus pasien terpapar virus COVID19. Penelitian ini bertujuan untuk mengetahui pelayanan Rumah Sehat COVID-19 sebagai inovasi pengendalian mortalitas dan morbiditas COVID-19. Metode penelitian yakni kualitatif desain studi kasus. Pengambilan data dengan wawancara, sampel purposive yakni Kepala Dinas Kabupaten Sukoharjo dan petugas kesehatan RSC. Analisa data yakni analisis tematik. Hasil dari penelitian ini adalah 1) Aspek legal dari RSC adalah Perbup Sukoharjo No.19/2020; 2) Persyaratan pasien adalah semua orang yang terkonfirmasi positif COVID-19 dan sedang tinggal di Sukoharjo; 3) Bangunan dan fasilitas penunjang layak (rekam medis, pendanaan, APD, swab test); 4) Pemerintah melakukan pendekatan kepada masyarakat setempat agar dapat menerima keberadaan RSC; 5) Pasien merasa nyaman; 6) Petugas kesehatan masih memiliki rasa khawatir saat penanganan; 7) RSC memberikan dampak angka kesembuhan. Yang perlu ditingkatkan oleh RSC adalah pengadaan layanan PCR kepada pasien yang telah diizinkan pulang dan karantina mandiri di rumah serta memberikan early support dan after care pada petugas kesehatan untuk mengurangi rasa khawatir yang mereka rasakan.
\end{abstract}

\begin{abstract}
One of the innovations made by the Sukoharjo Regency government in handling COVID-19 was to establish Rumah Sehat COVID-19 as a special isolation place for patients exposed to the COVID-19 virus. This study aimed to determine Rumah Sehat COVID-19 service as an innovation to control COVID-19 mortality and morbidity. The research method was a qualitative case study design. Data were collected by interview, purposive samples were the Head of the Sukoharjo Regency Office and the RSC health officer. Data analysis was thematic analysis. The results of this study were 1) The legal aspects of the RSC are Perbup Sukoharjo No.19/2020; 2) Patient requirements are all people who are confirmed positive for COVID-19 and currently living in Sukoharjo; 3) Adequate buildings and supporting facilities (medical records, funding, PPE, swab tests); 4) The government approaches the local community in order to accept the existence of the RSC; 5) Patients feel comfortable; 6) Health workers still have a sense of worry when handling; 7) RSC has an impact on the cure rate. It is needed to be improved by the RSC is the provision of PCR services to patients who have been allowed to go home and self-quarantine at home and provides early support and after care to health workers to reduce the worries they feel.
\end{abstract}

(C) 2021 Universitas Negeri Semarang

\footnotetext{
Alamat korespondensi:

Program Studi Kesehatan Masyarakat

Universitas Muhammadiyah Surakarta

E-mail: nuralis2009@ums.ac.id
} 


\section{PENDAHULUAN}

Pada akhir tahun 2019, dunia dihebohkan dengan adanya penyakit menular baru yang berasal dari virus SARS-Cov2 dari Wuhan, Cina. Perkembangan kasus ini akhirnya direspon oleh WHO sebagai Public Health Emergency of International Concern. Sampai tanggal 24 Juni 2020 pukul 14.00 WIB telah ada sebanyak 213 negara terkonfirmasi positif kasus SARS-Cov2 atau kemudian disebut sebagai pandemi COVID-19. Pemerintah Indonesia telah melakukan upaya nasional penanganan dan penanggulangan COVID-19 dengan membentuk gugus tugas percepatan dan penanganan COVID-19 yang mengeluarkan protokol dalam pandemi COVID-19 untuk sektor kesehatan, ekonomi, sosial, dan pendidikan ('Pedoman Penanganan Cepat Medis dan Kesehatan Masyarakat Covid-19 di Indonesia', 2020). Pemerintah telah menunjuk ratusan rumah sakit rujukan COVID-19 dan laboratorium pemeriksaan. Selain itu, pemerintah juga menyiapkan rumah sakit darurat khusus penanganan COVID-19 di Wisma Atlet yang salah satunya berfungsi sebagai tempat isolasi mandiri (Liputan6.com, no date).

Provinsi Jawa Tengah merupakan salah satu daerah di Indonesia dengan kasus COVID19 dengan angka kesembuhan tinggi. Sampai tanggal 24 Juni 2020 terlaporkan kasus positif sebanyak 3.333 dengan rincian $49,13 \%$ dirawat, $43,23 \%$ sembuh, dan 7,64\% meninggal (Jateng Tanggap COVID-19, no date). Kabupaten Sukoharjo memiliki total kasus positif COVID19 sembuh sebanyak 61 orang, 13 orang isolasi mandiri, meninggal 5 orang, dan dirawat 7 orang, sedangkan ODP 719 orang (664 selesai pemantauan, 42 isolasi mandiri, 8 rawat inap, 5 meninggal) dan PDP 33 orang (17 rawat inap, 7 isolasi mandiri, 97 negatif, 9 meninggal) (Sukoharjo Tanggap COVID-19, no date). Kabupaten Sukoharjo di dalam website https://corona.sukohariokab.go.id/

menyebutkan rumah sakit rujukan COVID-19 yakni RSUD Ir. Soekarno. Menariknya, pemerintah Kabupaten Sukoharjo membuat sebuah fasilitas rumah sehat COVID-19 yang digunakan bagi warga Sukoharjo yang positif COVID-19 tanpa gejala. Rumah sehat juga dilengkapi berbagai fasilitas seperti posko petugas medis, ruang dekontaminasi hingga konseling kejiwaan.

Proses isolasi yang digagas oleh Kabupaten Sukoharjo ini juga penting dilakukan karena mampu menjadi upaya asesmen cepat COVID-19. Melacak kontak orang yang kemungkinan terinfeksi COVID-19 dengan cara mengisolasi orang tersebut secepat mungkin diketahui dapat mengurangi lamanya orang menularkan COVID-19 di komunitas selama 4 minggu di Shenzhen, China, menurut hasil dari 391 kasus dan 1.286 kontak dekatnya (Tang et al., 2020). Namun terdapat hal yang perlu menjadi pertimbangan, dalam sebuah penelitian yang dilakukan di Pakistan disebutkan bahwa negara dengan pendapatan ekonomi rendah akan sangat sulit mengikuti jejak China dan Korea dalam penanganan COVID-19 yakni dengan Trace, Test, Treat karena sumber daya yang terbatas. Namun, hal tersebut dapat disiasati dengan menggunakan score card based assessment yang sangat berguna bila digunakan di daerah desa dan kota untuk meringankan perawatan pasien yang dicurigai COVID-19 (Shahzad et al., 2020).

Dalam buku pedoman yang dikeluarkan oleh Gugus Tugas Percepatan Penanganan COVID-19 diterangkan bahwa karantina fasilitas khusus adalah karantina yang dilakukan di fasilitas khusus yang disediakan oleh otoritas yang berwenang dan didasarkan kepada orang yang memiliki gejala dan riwayat kontak dengan seseorang yang positif. Yang termasuk ke dalam daftar orang yang dilakukan karantina rumah adalah ODP ('Pedoman Penanganan Cepat Medis dan Kesehatan Masyarakat Covid-19 di Indonesia', 2020). Karantina dalam fasilitas khusus ini dimanfaatkan sebagai salah satu pilihan untuk isolasi diri pasien positif COVID-19. Isolasi diri menjadi salah satu langkah efektif untuk mengurangi penyebaran virus SARS-Cov-2 (Razai et al., 2020; Kucharski et al., 2020; Marcel et al., 2020), lebih efektif lagi apabila 
diiringi dengan physical distancing dan contact tracking (Kucharski et al., 2020; Marcel et al., 2020).

Sehingga apa yang dilakukan pemerintah Sukoharjo dengan mendirikan Rumah Sehat COVID-19 di Sukoharjo menjadi strategi yang patut untuk dikaji. Pertanyaan utama dari penelitian ini adalah bagaimana pelayanan Rumah Sehat COVID-19 untuk inovasi pengendalian mortalitas dan morbiditas COVID-19 di Sukoharjo.

\section{METODE}

Metode yang digunakan dalam penelitian ini adalah kualitatif dengan desain studi kasus (Kusumawardani et al., 2015). Informan dari penelitian ini diambil dengan cara purposive yakni petugas kesehatan di Rumah Sehat COVID-19 dan Kepala Dinas Kabupaten Sukoharjo. Instrumen dari penelitian ini adalah pedoman wawancara yang dibuat oleh tim peneliti, serta dilengkapi dengan inform consent terlebih dahulu dijelaskan kepada informan. Pengumpulan data dilakukan dengan cara teknik wawancara mendalam di lokasi RSC pada bulan Agustus 2020 dengan menerapkan protokol kesehatan. Dari setiap wawancara yang dilakukan, peneliti membuat rangkuman hasil wawancara dan disampaikan kepada informan sebagai upaya trustworthiness data kualitatif yang didapatkan. Analisis data dilakukan dengan menggunakan analisis tematik yakni dengan mengelompokkan data yang didapatkan dalam tema-tema tertentu (Heriyanto, 2018).

\section{HASIL DAN PEMBAHASAN}

Berdasarkan hasil wawancara yang dilakukan kepada Kepala Dinas Kesehatan Kabupaten Sukoharjo, didapatkan informasi bahwa dasar hukum dari pendirian RSC ini adalah Peraturan Bupati Sukoharjo Nomor 19 tahun 2020 tentang Pedoman Penyediaan Ruang Isolasi Corona Virus Disease 2019 pada Kelurahan dan Desa di Kabupaten Sukoharjo seperti pada kutipan di bawah ini. “...didirikan berdasarkan Peraturan Bupati Sukoharjo No.19 2020. Jadi dasarnya adalah berdasarkan Peraturan Bupati." (P1)

Sementara untuk masa aktif dari RSC ini disampaikan oleh petugas kesehatan RSC adalah sampai Juni akhir, namun pihaknya sudah siap apabila diperpanjang sampai Juli karena status KLB di Sukoharjo ditetapkan sampai Juli seperti pada kutipan di bawah ini.

"SK pertama sampai mei, 29 Mei tapi kemudian setelah memang masih ada pasien yang hasil pemeriksaan PCR nya memenuhi syarat untuk keluar atau sembuh, sehingga kami diperpanjang sampai SK kedua yaitu juni akhir. Karena sukoharjo ini masa KLB nya diperpanjang sampai juli jadi mau tidak mau kita sudah disiapkan untuk lanjut." (P2)

Peraturan Bupati Sukoharjo No.19/2020 merupakan salah satu bentuk keseriusan pemerintah Sukoharjo dalam menangani pandemi COVID-19. Peraturan ini berisi tentang pedoman penyediaan ruang isolasi COVID-19 pada kelurahan dan desa di Kabupaten Sukoharjo. Terdapat 25 aturan hukum tertulis sebagai dasar terbentuknya perda ini. Beberapa diantaranya adalah Keputusan Presiden No.11/2020 tentang Penetapan Kedaruratan Kesehatan Masyarakat COVID-19, Peraturan Menteri Dalam Negeri Nomor 20/2020 tentang Percepatan Penanganan COVID-19 di Lingkungan Pemerintah Daerah (Berita Negara RI tahun 2020 Nomor 249) dan Peraturan Daerah Kabupaten Sukoharjo No.6/2014 tentang Penyelenggaran Penanggulangan Bencana. Maksud dari perbup ini adalah untuk memberikan pedoman kelurahan dan desa dalam menyediakan ruang isolasi sehingga dapat membatasi penularan COVID-19 dan bertujuan untuk memastikan bahwa ruang isolasi yang tersedia sesuai kriteria dan standar (Kabupaten Sukoharjo, 2020).

Peraturan bupati tergolong dalam peraturan kepala daerah (Perkada). Dalam UU RI Nomor 23 tahun 2014 pasal 246 ayat (1) Perkada memiliki fungsi sebagai peraturan pelaksana peraturan daerah (Perda). Perkada 
tersebut menjadi bagian yang tidak terpisahkan dari Perda. Keberadaannya tidak dapat diabaikan dan dilupakan, karena Perda tanpa Perkada dapat menimbulkan ketidakpastian dalam penegakan Perda. Sedangkan Perkada tidak pernah ada tanpa delegasi dari Perda (Mufidah, 2017). Sehingga perbup ini dinilai telah sesuai dengan hierarki perundangan yang ada.

Kepala Dinkes Kab.Sukoharjo mengatakan bahwa pasien yang dirawat di RSC adalah orang yang telah melakukan swab test dan hasilnya positif seperti pada kutipan di bawah ini.

"pasien pasien yang dirawat di RSC (Rumah Sehat Covid) adalah pasien yang sudah melewati pemeriksaan swap/VCA dan hasilnya adalah positif begitu." (P1)

Awalnya hanya dikhususkan bagi pasien tanpa gejala, namun kemudian berkembang untuk pasien dengan gejala ringan atau dengan komorbid yang terkendali. Hal ini disampaikan oleh Kepada Dinas Kesehatan Kabupaten Sukoharjo seperti pada kutipan di bawah ini.

"Nah, setelah melewati diskusi dan koordinasi dengan beberapa pihak akhirnya disitu yang dirawat tidak hanya kasus positif tanpa gejala tetapi juga akhirnya kasus positif dengan gejala ringan atau demgan komorbit yang terkendali." (P1)

Yang patut diapresiasi adalah pasien yang diterima adalah semua orang yang terkonfirmasi positif COVID-19 dan sedang tinggal di Sukoharjo, tidak terbatasi oleh identitas di KTP. Hal ini disampaikan oleh Kepada Dinas Kesehatan Kabupaten Sukoharjo seperti pada kutipan di bawah ini.

"...kami ini untuk yang ini tidak memandang beliau dari asal wilayah manaltidak melihat KTPnya yang penting beliau saat ini dilakukan pelayanan kesehatannya di kabupaten sukoharjo." (P1)

Mengacu pada Perbup Sukoharjo
No.19/2020, ruang isolasi diperuntukkan bagi Orang Tanpa Gejala (OTG), Orang Dalam Pemantauan (ODP), Pasien Dalam Pengawasan (PDP) gejala ringan dan terkonfirmasi positif COVID-19 tanpa gejala. Sehingga Rumah Sehat COVID-19 Sukoharjo ini sudah sesuai dengan peruntukannya. Selain itu, RSC juga sudah sesuai dengan pedoman Penanganan Cepat Medis dan Kesehatan Masyarakat untuk status pasien yakni ODP usia diatas 60 tahun dengan penyakit penyerta yang terkontrol, PDP Gejala Sedang/mandiri.tanpa sesak nafas/tanpa pneumonia, Pasien COVID-19 positif tanpa penyakit lain dan tanpa sesak nafas/tanpa pneumonia ('Pedoman Penanganan Cepat Medis dan Kesehatan Masyarakat Covid-19 di Indonesia', 2020). Ruang isolasi khusus ini bermanfaat bagi mereka yang tidak bisa isolasi mandiri di rumah karena kondisi rumah yang tidak standar untuk isolasi atau jumlah anggota keluarga banyak. Isolasi sangat bermanfaat untuk mengurangi kepadatan terduga COVID19 di masyarakat sehingga mengurangi potensi penularan COVID-19 (Mona, 2020) dan penelitian di China menyebutkan bahwa untuk menghadapi ketidakpastian COVID-19 perlu meningkatkan upaya strategi karantina, isolasi dan tingkat deteksinya (Tang et al., 2020).

Gedung yang digunakan sebagai RSC ini bukan milik pemerintah daerah Kabupaten Sukoharjo, namun merupakan gedung milik kepolisian yang disebut sebagai Dalmas. Untuk saat ini, di masa KLB Sukoharjo, gedung ini sangat dibutuhkan namun mungkin setelah memasuki masa era normal dan semua masyarakat sudah beradaptasi baik dengan COVID-19 maka gedung ini tidak diperlukan lagi sebagai RSC. Hal ini disampaikan oleh Kepada Dinas Kesehatan Kabupaten Sukoharjo seperti pada kutipan di bawah ini.

"Karena memang rumah ini kita dirikan awal bukan punya pemerintah daerah. Jadi ini adalah pinjaman dari rekan rekan kita di kepolisian mereka punya dalmas ....." (P1)

Fasilitas yang ada di RSC terdiri dari tempat tidur sejumlah 27 buah, Wifi dan TV, 
namun masih dirasa kurang di ruang petugas dan ruang perawatan. Hal ini disampaikan oleh Kepada Dinas Kesehatan Kabupaten Sukoharjo dan Tenaga Kesehatan RSC seperti pada kutipan di bawah ini.

\section{"jadi RSC sendiri ada 27 bed" (P1)}

"Untuk fasilitas Alhamdulillah cukup, sudah ada wifi, TV, hanya saja kekurangannya di ruang petugas dan di ruang perawatan" (P3)

Berdasarkan Perbup tersebut, ruang isolasi bisa berasal dari sekolah, balai desa, rumah warga yang disewakan dan fasilitas umum lainnya. RSC menggunakan fasilitas bangunan dari kepolisian Sukoharjo dan sesuai dengan standar ruang isolasi yang tertera dalam peraturan, yakni memiliki ventilasi baik, pencahayaan baik, bahan konstruksi tidak lembab, luas ruangan cukup, terdapat ruang terbuka hijau yang memadai dan terdapat sarana Mandi, Cuci, Kakus (MCK). Sementara untuk fasilitas pendukung, berdasarkan Perbup harus memiliki tempat tidur yang layak, jaringan wifi, APD, alat kebersihan dan alat pemeriksaan kesehatan. Sehingga RSC termasuk dalam kategori baik dalam melengkapi fasilitas pendukungnya. Ketersediaan bangunan yang baik dan fasilitas pendukung yang memadai kemungkinan akan membuat pasien yang sedang menjalani isolasi merasa lebih nyaman.

Catatan medis pasien yang ada di RSC dilakukan oleh petugas kesehatan yang ada di RSC tersebut. Hal yang dicatat antara lain yakni hasil asesmen pasien dari puskesmas, keluhan yang timbul selama perawatan, dan evaluasi swab test pasien tersebut.

“.......kami juga menyiapkan catatan pasien yang oleh teman teman disebut rekam medis jadi bagaimana kondisi pasien pada saat masuk awal dengan asesmen yang sudah dilakukan oleh teman teman yang ada di puskesmas dan berikutnya selama perawatan disana itu mendapat keluhan apa lalu berikutnya saat dilakukan evaluasi swab test hasilnya bagaimana itu tercatat semua disana secara manual untuk sementara ini". (P1)
Dalam penjelasan Pasal 46 ayat (1) UU No. 29 Tahun 2004 tentang Praktik Kedokteran, yang dimaksud dengan rekam medis adalah berkas yang berisi catatan dan dokumen tentang identitas pasien, pemeriksaan, pengobatan, tindakan dan pelayanan lain yang telah diberikan kepada pasien. Rekam medik sangat penting selain untuk diagnosis dan pengobatan juga untuk evaluasi pelayanan kesehatan, peningkatan efisiensi kerja melalui penurunan mortalitas dan motilitas serta perawatan penderita yang lebih sempurna (Kholili, 2011). Ketersediaan rekam medis bagi pasien RSC ini sangat membantu untuk memantau kondisi pasien dari awal sampai akhir terapi yang dilakukan di RSC.

Dana untuk operasional RSC berasal dari Anggaran Pendapatan Belanja Daerah (APBD) Kabupaten Sukoharjo yang kemudian dilimpahkan menjadi Dana Tak Terduga di bawah tanggung jawab Pemerintah Kabupaten Sukoharjo selama masa KLB COVID-19 ini.

"untuk pendanaan RSC itu sepenuhnya dari Anggaran Pendapatan Belanja Daerah Kabupaten Sukoharjo yang dilimpahkan biaya tak terduga yang menjadi tanggung jawab Dinas Kesehatan Kabupaten Sukoharjo selama pandemi" (P1)

Apabila status KLB sudah dicabut namun kasus COVID-19 masih ada dan membutuhkan isolasi khusus, maka pembiayaan diajukan melalui anggaran perubahan APBD.

"pembiayaan itu diajukan melalui anggaran perubahan di $A P B D$ " (P1)

Kerjasama dalam pendanaan juga terbuka lebar dengan syarat persetujuan dari pemerintah daerah Kabupaten Sukoharjo.

"ada perjanjian kerjasama yang bisa kami lakukan dengan persetujuan pemerintah daerah" (P1)

Pemerintah pusat melalui Kementerian Keuangan juga telah mengeluarkan aturan tertulis refocusing APBD untuk penanganan dan 
pencegahan COVID-19 di daerah berupa 9 peraturan pemerintah, 5 surat pemberitahuan ke daerah dan 9 kebijakan (Direktorat Jenderal Perimbangan Keuangan, no date). Perbup Sukoharjo No. 19/2020 menyebutkan bahwa sumber pendanaan untuk ruang isolasi adalah APBD, APB Desa dari Pos Dana Desa dan sumbangan dari pihak ketiga atau sumber dana lain yang tidak mengikat. APBD kemudian dialihkan menjadi Dana Tak Terduga. Berdasarkan hal tersebut, pemerintah Kabupaten Sukoharjo telah sesuai melakukan aturan refocusing APBD sesuai mandat dari pemerintah pusat dan pendanaan RSC telah sesuai dengan peraturan yang ada.

Alat Pelindung Diri digunakan oleh seluruh tenaga kesehatan RSC sesuai SOP yang telah diajarkan pada saat pelatihan di RSUD. Sebelum tenaga kesehatan pulang ke rumah, tenaga kesehatan mandi terlebih dahulu dan sesampainya di rumah pun mandi lagi.

"Ya untuk APD sebisa mungkin sesuai SOP sebelum kita pulang kita ganti mandi sampe rumah mandi lagi. Bahkan kita memakai APD pun kemaren juga sebelum kita masuk kesini hari pertama itu kita sudah diajari dari RSUD di TPI nya." (P2)

Alat pelindung diri yang diperlukan oleh tim medis adalah masker medis, sarung tangan karet panjang, cover all, kacamata gogle, sepatu boot, apron dan penutup kepala. APD sangat penting digunakan selama masa pandemi COVID-19 ini karena untuk mengurangi terjadinya kontak atau droplet yang terjadi dengan pasien. Prosedur penggunaan APD diatur saat penggunaan ataupun pelepasannya. Petugas kesehatan menggunakan APD saat berada di dekat ruang pasien dan sebelum menggunakannya harus cuci tangan dengan sabun. Sementara untuk melepaskan APD menjadi tantangan tersendiri bagi petugas kesehatan, diperlukan perhatian yang cermat. Kapan pun memungkinkan, minta pengamat mengawasi Anda saat Anda melepas APD untuk memastikan tidak ada pelanggaran dalam teknik. Pengangkatan APD harus dimulai di kamar pasien (Ortega et al., 2020).
Di RSC juga diberikan fasilitas swab untuk pasien. Pertama dilakukan bila hasil rapid test hasilnya positif, kemudian selang empat belas hari dilakukan evaluasi swab pertama. Apabila hasil evaluasi pertama hasilnya positif selang 7 hari dilakukan swab test lagi, namun bila hasilnya negatif maka selang 3 hari dilakukan swab test lagi. Bila hasil swab test 2 kali berturut-turut hasilnya negatif, maka pasien tersebut baru dinyatakan sembuh.

"dari rapid positifkita lakukan swap pertama, jika swap pertama itu positif nanti hari keempat belas itu dilakukan swap evaluasi yang pertama. Kemudian kalo dari evaluasi yang pertama itu positif nanti dilakukan swap lagi selang 7 hari. Tapi jika negative, negative nya baru satu kali tetap dilakukan swap lagi di hari ketiga minimal. Baru jika kalo negative 2 kali berturut turut baru dinyatakan sembuh." (P2)

"sembuh yang ditandai dengan pemeriksaan swap 2 kali berturut turut negative." (P1)

Swab test adalah tes untuk diagnosa COVID-19 dengan cara pengambilan cairan di tenggorokan dengan sampel lendir yang diambil dari hidung atau tenggorokan, hasil tes memerlukan waktu beberapa jam atau beberapa hari, metode RT-PCR (Polymerase Chain Reaction), hanya tersedia di rumah sakit dengan biosafety cabinet dan sampelnya diperiksa di laboratorium Biosafety Level (BSL) II, kelebihannya dapat mendeteksi virus SARSCOV2 (penyebab Covid-19) di tubuh seseorang dan kekurangannya pemeriksaanya lebih rumit dan membutuhkan waktu yang lebih lama (Hotline, 2020). Beberapa faktor yang mempengaruhi tes RT-PCR untuk COVID-19 adalah sensitivitas dan spesifisitas tes yang digunakan, tipe sampel yang digunakan, waktu pengambilan sampel, target gen yang digunakan dan kemungkinan adanya mutasi virus (Patel et al., 2020). Pasien dalam fase penyembuhan (sudah dua kali tes NAAT negatif) harus tetap diperiksa secara regular dan melakukan karantina mandiri di rumah selama 14 hari karena ada bukti yang menunjukkan bahwa pasien tersebut masih mungkin menjadi 
positif kembali pada tes berikutnya (Chen et al., 2020). Sehingga disimpulkan bahwa prosedur yang dilakukan oleh RSC untuk pasien yang diisolasi sudah sesuai dengan panduan yang ada. Terkait dengan penerimaan masyarakat, pertama, terjadi penolakan oleh masyarakat sekitar bangunan dalmas, karena dianggap bila ada tempat untuk isolasi pasien COVID-19 dikhawatirkan bisa masyarakat sekitar bangunan tersebut akan tertular. Namun kemudian penolakan masyarakat tersebut diselesaikan dengan cara damai dengan melakukan pendekatan kepada camat, kepala desa dan warga setempat. Setelah upaya tersebut dilakukan, akhirnya masyarakat setempat bersedia menerima keberadaan tempat isolasi khusus tersebut.

"Saat kita menyiapkan saja diawal, menyiapkan bangunan di awal sudah ada masyarakat disekitar situ yang memberikan penolakan beliau tidak mau wilayah di dekatnya itu ada rumah karantina yang notabene nya digunakan untuk kasus positif. Mereka khawatir kalo nanti tetangga sekitarnya akan tertular. Tapi setelah dilakukan edukasi Alhamdulillah dengan perangkat desa disitu dan kecamatan berikutnya masyarakat akhirnya bisa menerima." (P1)

Kedua, masyarakat masih memiliki keraguan bahwa pasien yang dinyatakan sembuh dan diperbolehkan pulang tersebut belum benar-benar sembuh dari COVID-19. Sehingga perlu dilakukan edukasi kepada masyarakat setempat dan memberikan pasien tersebut surat keterangan telah sembuh dari COVID-19 agar mampu kembali ke dalam kehidupan sosial masyarakatnya.

"Kemarin sempat ya ada kasus yang lingkungan sekitar masih tidak yakin bahwa si pasien ini pulang dengan keadaan betul betul sehat dan bisa beraktivitas kembali. Nah itu yang akhirnya dibutuhkan edukasi kembali untuk kasus penanganan COVID itu edukasi yang benar dan jelas." (P1)

Penerimaan masyarakat terhadap pasien positif COVID-19 cenderung negatif. Penerimaan tersebut kemudian cenderung disebut sebagai stigma negatif. Stigma sosial dalam konteks kesehatan adalah hubungan negatif antara seseorang atau sekelompok orang yang berbagi karakteristik tertentu dan penyakit tertentu (WHO, 2020). Stigma dapat mendorong orang untuk menyembunyikan penyakit untuk menghindari diskriminasi, mencegah orang mencari perawatan kesehatan segera dan mencegah mereka untuk mengadopsi perilaku sehat (Abudi, Mokodompis and Magulili, 2020). Stigma sosial ini disebabkan oleh tiga faktor yakni ini adalah penyakit baru dan masih banyak hal yang belum diketahui tentangnya, masyarakat seringkali takut akan hal yang tidak diketahui dan mudah saja mengasosiasikan rasa takut itu dengan orang lain (WHO, 2020). Sementara untuk mengatasi terjadinya stigma negatif ini WHO merekomendasikan untuk melakukan diskusi terbuka terhadap masyarakat setempat (Bagcchi, 2020). Berdasarkan hal tersebut, maka pendekatan kepada tokoh masyarakat setempat dan masyarakat yang dilakukan oleh RSC sangat tepat digunakan.

Menurut hasil wawancara dengan petugas kesehatan yang ada di RSC Kab.Sukoharjo, pasien merasa nyaman dirawat di tempat tersebut dan tidak merasa kesulitan dalam berkomunikasi dengan keluarga.

"Nah, kita sudah mencoba melakukan rujukan ke rumah sakit setempat tapi setelah sampai sana dilakukan pemeriksaan diberi obat, pasien itu tidak kerasan dirawat disana, minta balek kesini karena mereka lebih merasa nyaman disini. Karena kalo dirumah sakit kan perawatannya tidak seperti disini. Kalo disinikan mereka masih bisa beraktifitas, ibadah dan semuanya tidak dibatasi yang artinya beribadah pun mereka masih oke" (P2)

Dengan konsep sehat yang digagas, RSC melakukan pelayanan tidak hanya memberikan terapi obat namun juga terapi psikososial serta tempat tinggal yang nyaman. Selain itu, saat lebaran Idul Fitri yang lalu, RSC juga mengizinkan pasien untuk dijenguk oleh 
keluarga dengan tetap mematuhi protokol kesehatan yang ada.

“...tidak hanya terapi obat saja yang kita berikan tetapi terapi phsyco social juga kita berikan serta keadaan dan tempat tinggal yang nyaman..." (P2)

Salah satu faktor yang menentukan pasien nyaman dalam perawatan adalah karena pelayanan yang diberikan sangat dibutuhkan dan dilakukan dengan sangat baik oleh petugas kesehatan. Pelayanan yang berbeda diberikan di tempat karantina khusus adalah pelayanan psikososial. Dukungan psikososial tidak kalah pentingnya dengan pengendalian infeksi selama epidemi, dan kolaborasi dan jejaring merupakan inti dari manajemen bencana. Dengan demikian, tim multidisiplin profesional kesehatan mental segera dibentuk dan telah berkolaborasi secara efektif dengan pemangku kepentingan internal dan eksternal untuk dukungan psikososial selama wabah COVID-19 (Hyun et al., 2020).

Petugas kesehatan yang ada di RSC mengaku tetap merasakan khawatir ketika harus berhadapan langsung dengan pasien COVID-19. Namun, petugas kesehatan telah menyiapkan diri dengan APD yang disarankan dan telah mengikuti pelatihan penggunaan APD dari RSUD di TPI.

"Tantangannya ya kita kan juga kontak langsung dengan pasien yang terconfirm kita juga ada rasa was-was, takut terus ada rasa khawatir kalo pulang ke rumah kita masih bawa virusnya soalnya kan dirumah ada anak-anak, keluarga dan tetangga". (P2)

Penelitian yang telah dilakukan di tiga rumah sakit dan sembilan layanan kesehatan pada bulan April 2020 menunjukkan hasil bahwa terdapat pengaruh usia, status keluarga, kejujuran pasien, ketersediaan APD dan pengetahuan terhadap kecemasan petugas dan ketersediaan APD menjadi faktor paling berpengaruh (Fadli et al., 2020). Sehingga perasaan khawatir yang dialami oleh petugas kesehatan di RSC adalah wajar terjadi. Dalam sebuah penelitian Managing mental health challenges faced by healthcare workers during covid-19 pandemic dijelaskan bahwa dukungan yang harus diberikan oleh manajemen RS kepada petugas kesehatan, yakni Early Support dan After Care. Early support dijelaskan 1) pemimpin tim harus menjelaskan apa saja yang harus dilakukan dan risikonya secara jelas dan selalu membentuk forum diskusi, 2) proses dukungan rutin (seperti program dukungan sebaya) tersedia untuk staf pelayanan kesehatan harus mencakup pengarahan tentang moral injury, serta kesadaran akan penyebab lain penyakit kesehatan mental dan apa yang harus diwaspadai. Sementara untuk AfterCare The National Institute for Health and Care Excellence merekomendasikan "pemantauan aktif" staf untuk memastikan bahwa minoritas yang menjadi tidak sehat diidentifikasi dan dibantu mengakses perawatan berbasis bukti (Greenberg et al., 2020).

Dari sejak awal berdiri (11 Mei 2020) sampai dengan tanggal 18 Juni 2020, dilaporkan bahwa dari 25 pasien yang terdata di RSC, sudah 6 orang yang dipulangkan dalam keadaan sembuh. Isolasi sangat bermanfaat untuk mengurangi kepadatan terduga COVID-19 di masyarakat sehingga mengurangi potensi penularan COVID-19 (Mona, 2020). Dengan kesembuhan pasien yang dirawat di RSC, maka diharapkan dapat memutus tali penyebaran virus ini.

"Ada sekitar 6 kasus yang sudah kami pulangkan dengan hasil evaluasi swap 2 kali berturut turut dan hasilnya negative." (P1)

Pasien yang dinyatakan sembuh diberikan resume kondisi pasien selama dirawat, hasil laboratorium, serta surat edukasi. Surat edukasi ini berisi tentang cara melakukan isolasi mandiri untuk mencegah terjadinya reinfeksi COVID-19. Edukasi dapat meningkatan pengetahuan seseorang terhadap suatu hal atau isu terbaru. Dengan pemberian edukasi yang benar dan oleh petugas yang kompeten di bidangnya, diharapkan dapat menghilangkan 
terjadinya kesalahan informasi atau timbulnya stigma negatif.

“.....berikutnya surat edukasi yang kami sampaikan termasuk didalamnya ada edukasi tentang tetap melakukan isolasi mandiri untuk mencegah reinfeksi dan apa saja yang mesti dilakukan selama nanti di rumah. Jadi protokol kesehatan tetap dilaksanakan supaya beliau sendiri tetap kondisinya sehat dan keluarga lain yang ternyata kemungkinan kita statusnya tidak tahu, mungkin ada saudaranya pulang dan sebagainya kita statusnya tidak tahu itu juga tidak menularkan atau memberikan infeksi yang lain kepada pasien tersebut" (P1)

Pasien yang dirawat di RSC, keluarganya di rumah akan diberikan bantuan sembako dan Bantuan Langsung Tunai (BLT) dari gugus tugas setempat atau pun bantuan lain dari masyarakat setempat karena nilai gotong royong yang masih dijunjung tinggi oleh masyarakat sekitar. Sehingga pasien yang mungkin menjadi kepala rumah tangga selama masa perawatan tersebut keluarga di rumah terjamin kehidupan kesehariannya. Keluarga pasien yang ditinggalkan untuk isolasi beberapa hari atau bahkan minggu pasti akan mengalami perbedaan, apalagi bila yang diisolasi adalah kepala rumah tangga. Penghasilan inti keluarga pasti berkurang atau bahkan tidak ada. Sehingga keluarga pasien perlu diberikan dukungan materiil untuk mencukupi kebutuhan seharihari.

"Setiap bulan ada bantuan sembako dan juga ada BLT. Jadi keluarga keluarga tersebut kan kita juga sudah punya datanya, lalu kita ajukan ke gugus tugas setempat lalu diberikan-lah bantuan tersebut. Juga selain bantuan sosial dan BLT juga ada bantuan yang diberikan oleh masyarakat di sekitar..." (P1)

\section{PENUTUP}

Berdasarkan hasil penelitian disimpulkan bahwa aspek legal dari RSC ini sudah jelas dan sesuai hirarki perundang-undangan, pasien yang diisolasi sesuai dengan kriteria dalam aspek legalnya, sarana dan prasarana sudah baik, masyarakat dapat diarahkan untuk menerima adanya RSC dan orang-orang yang diisolasi didalamnya, pasien yang dirawat merasakan nyaman di RSC, petugas masih memiliki rasa khawatir saat bertugas, dan RSC memberikan dampak yang baik dalam mengurangi mortalitas atau morbiditas pasien COVID-19.

Sementara beberapa hal yang perlu ditingkatkan oleh RSC adalah pengadaan layanan PCR kepada mantan pasien yang telah diizinkan pulang dan karantina mandiri di rumah dan memberikan early support dan after care pada petugas kesehatan untuk mengurangi rasa khawatir yang mereka rasakan.

\section{DAFTAR PUSTAKA}

Abudi, R., Mokodompis, Y. and Magulili, A. N. (2020) 'Stigma Terhadap Orang Positif Covid19', Jambura Journal of Health Sciences and Research, 2(2), pp. 77-84. doi: $10.35971 /$ jjhsr.v2i2.6012.

Bagcchi, S. (2020) Stigma during the COVID-19 pandemic, The Lancet Infectious Diseases. doi: 10.1016/S1473-3099(20)30498-9.

Chen, D. et al. (2020) 'Recurrence of positive SARSCoV-2 RNA in COVID-19: A case report', International Journal of Infectious Diseases, 93, pp. 297-299. doi: 10.1016/j.ijid.2020.03.003.

COVID Live Update: 174,752,671 Cases and 3,762,974 Deaths from the Coronavirus - Worldometer (no date).

Direktorat Jenderal Perimbangan Keuangan | Kebijakan Transfer Ke Daerah Untuk Penanganan dan Pencegahan COVID-19 (no date).

Fadli, F. et al. (2020) 'Faktor yang Mempengaruhi Kecemasan pada Tenaga Kesehatan Dalam Upaya Pencegahan Covid-19', JURNAL PENDIDIKAN KEPERAWATAN INDONESIA, 6(1), pp. 57-65. doi: 10.17509/jpki.v6i1.24546.

Greenberg, N. et al. (2020) 'Managing mental health challenges faced by healthcare workers during covid-19 pandemic', The BMJ. BMJ Publishing Group. doi: 10.1136/bmj.m1211.

Gugus Tugas: 60 Persen Daerah di Indonesia Masuk Zona Hijau Covid-19 (no date).

Heriyanto, H. (2018) 'Thematic Analysis sebagai Metode Menganalisa Data untuk Penelitian 
Kualitatif', Anuva, 2(3), p. 317. doi: 10.14710/anuva.2.3.317-324.

Hotline, L. (2020) 'Beda Rapid Test , Sw dalam Deteksi Virus Corona', Kementrian Kesehatan dan Badan Nasional Penanggulangan Bencana.

Hyun, J. et al. (2020) 'Psychosocial support during the COVID-19 outbreak in Korea: Activities of multidisciplinary mental health professionals', Journal of Korean Medical Science, 35(22), pp. 113. doi: 10.3346/JKMS.2020.35.E211.

Jateng Tanggap COVID-19 (no date).

Kabupaten Sukoharjo (2020) PEDOMAN PENYEDIAAN RUANG ISOLASI CORONA VIRUS DISEASE 2019 PADA KELURAHAN DAN DESA DI KABUPATEN SUKOHARJO 2020. Kabupaten Sukoharjo.

Keistimewaan Wisma Atlet Sebagai Rumah Sakit Darurat Corona COVID-19 - Health Liputan6.com (no date).

Kholili, U. (2011) 'Pengenalan Ilmu Rekam Medis Pada Masyarakat Serta Kewajiban Tenaga Kesehatan di Rumah Sakit', Jurnal Kesehatan Komunitas, 1(2), pp. 60-72. doi: 10.25311/keskom.vol1.iss2.12.

Kucharski, A. J. et al. (2020) 'Effectiveness of isolation, testing, contact tracing, and physical distancing on reducing transmission of SARSCoV-2 in different settings: a mathematical modelling study', The Lancet Infectious Diseases, 20(10), pp. 1151-1160. doi: 10.1016/S14733099(20)30457-6.

Kusumawardani, N. et al. (2015) Penelitian Kualitatif $d i$ Bidang Kesehatan, Yogyakarta: PT Kanisius.

Marcel, S. et al. (2020) 'COVID-19 epidemic in Switzerland: On the importance of testing, contact tracing and isolation', Swiss Medical Weekly, 150(11-12), pp. 4-6. doi: 10.4414/smw.2020.20225.

Mona, N. (2020) 'KONSEP ISOLASI DALAM JARINGAN SOSIAL UNTUK MEMINIMALISASI EFEK CONTAGIOUS
(KASUS PENYEBARAN VIRUS CORONA DI INDONESIA)', Jurnal Sosial Humaniora

Terapan, 2(2). doi: 10.7454/jsht.v2i2.86.

Mufidah, L. (2017) 'EKSISTENSI PERATURAN KEPALA DAERAH SEBAGAI PERATURAN PELAKSANA PERATURAN DAERAH', Badamai Law Journal, 2(1), p. 59 . doi: 10.32801/damai.v2i1.3387.

Ortega, R. et al. (2020) 'Personal Protective Equipment and Covid-19', New England Journal of Medicine, 382(26), p. e105. doi: $10.1056 /$ nejmvcm 2014809.

Patel, R. et al. (2020) 'Report from the american society for microbiology covid-19 international summit, 23 march 2020: Value of diagnostic testing for sars-cov-2/covid-19', $m$ Bio. American Society for Microbiology. doi: $10.1128 / \mathrm{mBio} .00722-20$.

'Pedoman Penanganan Cepat Medis dan Kesehatan Masyarakat Covid-19 di Indonesia' (2020) 23 Maret, pp. 1-38.

Razai, M. S. et al. (2020) 'Coronavirus disease 2019 (covid-19): A guide for UK GPS', The BMJ, 368(March), pp. 1-5. doi: 10.1136/bmj.m800.

Rumah Sehat Covid-19 Sukoharjo Dibuka, 5 Pasien Positif Tanpa Gejala Dijemput Dari Rumah (no date).

Shahzad, N. et al. (2020) 'Rapid assessment of COVID-19 suspected cases: A community based approach for developing countries like Pakistan', Journal of Global Health, 10(1), pp. 1-5. doi: 10.7189/JOGH.10.010353.

Sukoharjo Tanggap COVID-19 (no date).

Tang, B. et al. (2020) 'The effectiveness of quarantine and isolation determine the trend of the COVID-19 epidemics in the final phase of the current outbreak in China', International Journal of Infectious Diseases, 95, pp. 288-293. doi: 10.1016/j.ijid.2020.03.018.

WHO (2020) 'Panduan untuk mencegah dan mengatasi stigma sosial', Unicef, pp. 1-5. 